\title{
Clinical Nurse Instructor Competencies: An Exploratory Study of Role Requirements
}

\author{
Natalie A. Bownes \\ University of Windsor, nbownes@uwindsor.ca \\ Michelle A. Freeman \\ University of Windsor, mfreeman@uwindsor.ca
}

Follow this and additional works at: https://qane-afi.casn.ca/journal

Part of the Adult and Continuing Education and Teaching Commons, and the Other Nursing Commons

\section{Recommended Citation}

Bownes, Natalie A. and Freeman, Michelle A. (2020) "Clinical Nurse Instructor Competencies: An Exploratory Study of Role Requirements," Quality Advancement in Nursing Education - Avancées en formation infirmière: Vol. 6: Iss. 3, Article 5.

DOI: https://doi.org/10.17483/2368-6669.1226

This Article is brought to you for free and open access by Quality Advancement in Nursing Education - Avancées en formation infirmière. It has been accepted for inclusion in Quality Advancement in Nursing Education - Avancées en formation infirmière by an authorized editor of Quality Advancement in Nursing Education - Avancées en formation infirmière. 


\section{Clinical Nurse Instructor Competencies: An Exploratory Study of Role Requirements}

\section{Cover Page Footnote}

I would like to thank Dr. Maher El-Masri for his guidance with statistical analysis for this research project. Je tiens à remercier le Dr Maher El-Masri pour ses conseils au sujet de l'analyse statistique dans le cadre de ce projet de recherche. 
Baccalaureate nursing education consists of a combination of theoretical and practical education that prepares students to assume the role of competent care providers. The application of knowledge and skills in the clinical setting is acknowledged as a vital component of undergraduate nursing curricula worldwide. Clinical experiences bridge the theory-to-practice gap, allowing students to practice in real-life settings (Carlson, 2015). These experiences play an important role in shaping nursing students' professional identities and values (Dahlke et al., 2012).

Historically, in nursing education, full-time nursing faculty taught in both classroom and clinical settings. Several changes in nursing schools have altered this role. In Canada, nursing education has changed from diploma education to a baccalaureate degree program as the minimum entry to practice standard (Canadian Association of Schools of Nursing [CASN], 2012). Faculty have been required to shift their focus to classroom teaching, grant applications, research, graduate student supervision, community service, and committee work (Dahlke et al., 2012; Oermann, 2015; Penn et al., 2008; Wong \& Wong, 1987). In addition, the projected shortage in the number of doctorally-prepared faculty and large increase in the number of Canadian nursing students has strained the supply of educators; this has resulted in many nursing schools relying on part-time clinical instructors (CIs) to assume the clinical education role (CASN, 2015; Canadian Institute for Health Information [CIHI], 2017; Canadian Nurses Association [CNA], 2019). Although these educators are hired for their clinical expertise, there is a growing recognition of the need for rolespecific competencies to guide the preparation for this increasingly important specialty (Andrew et al., 2010; Hewitt \& Lewallen, 2010).

A comprehensive review of the literature related to role requirements of CIs supported this concern but offered little direction on how to address the problem. A search was conducted using Google and Google Scholar to determine the specific title and definition of nursing CIs. An extensive review of the literature was completed using the electronic databases Cumulative Index to Nursing (CINAHL), Pubmed, ProQuest, and Medline via Ovid, as well as ancestry searching and grey literature. The following keywords were used singly or in combination in either full or truncated forms during the searches: "clinical instructor," "clinical instruction," "clinical teaching," "clinical education," and "nurse educator" and were restricted to nursing contexts. The search results were then limited to include peer-reviewed, full-text articles that were written in English from 2000 to 2018 and focused on clinical instructor preparation. Exceptions were made for six articles published outside of the initial search years because of their relevance. Exclusion criteria included material that focused on students' and academic faculty perceptions of clinical instructors' roles. Anecdotal reports were excluded.

Much of the research concentrated on the broader role of the nurse educator, which included instruction of both theory and clinical. Studies focusing on clinical instructors examined the nursing students' perceptions of their effectiveness (Knox \& Mogan, 1987; Nehring, 1990) and the experience of new clinical instructors in this role (Dahlke et al., 2012). Many studies were limited by small sample size and were conducted at a single school (Blauvelt \& Spath, 2008; O'Rae et al., 2017; Reid et al., 2013). Guidelines developed to assist nurses with educating, precepting, or mentoring undergraduate nursing students were of limited use in defining specific competencies required for the unique role of clinical instructor (Registered Nurses' Association of Ontario [RNAO], 2016). A new approach is required to identify role-specific competencies for the CI. The change in educational roles in nursing schools, the lack of a competency framework specific to clinical instructors, and the lack of recognition of clinical teaching as a specialty has left CIs feeling disconnected and ill prepared to manage their growing responsibilities (Carlson, 2015). A national 
approach to standardized competencies for CIs is needed to support nursing programs in preparing nursing students for an evolving RN role.

\section{Background}

Although various terms are used for the role (e.g., clinical nurse educator), the Canadian Nurse Educator Institute [CNEI] (2019) uses the title of clinical instructor and defines it as a nurse who teaches in a wide range of practice settings to prepare students to meet entry to practice competencies. This definition effectively articulates the CI role for the purpose of this study. Many authors have outlined the complex and multidimensional role that CIs perform in nursing programs: they socialize students to the nursing profession, link classroom theory to practice, and shape the clinical learning experiences to ensure they meet provincial entry to practice competencies (Arnold \& Boggs, 2016; Dahlke et al., 2012; Jennings \& Brett, 2018; Oermann, 2015; World Health Organization [WHO], 2016). To fulfill the role expectations, they must have knowledge of professional nursing standards and current clinical practices, understand and apply theories and principles of adult education, guide the students who require more support while offering more challenging opportunities to students who are excelling (Oermann, 2015; Zabat Kan \& Stabler-Haas, 2014), and evaluate student nurses' application of knowledge to practice (Arnold \& Boggs, 2016; CASN, 2015; WHO, 2016; Zabat Kan \& Stabler-Haas, 2014). CIs need to focus not only on individual student's learning needs but also on the learning needs of the group and the care provided to patients (Jennings \& Brett, 2018). They are required to be adept at working with the different informatics systems (e.g., learning management system, electronic medical records) at the nursing school and in the practice settings (CASN, 2013; Gazza \& Shellenbarger, 2005; Pilarski, 2011). In addition, CIs are the "face" of the nursing school and assume the important role of agency liaison by creating partnerships between the practice setting and the educational institution (RNAO, 2016; Zabat Kan \& Stabler-Haas, 2014).

Because of the complexities of this role, it is now recognized that clinical instructors require a formal education program, and new online certificate programs have emerged (Bloomberg Faculty of Nursing, 2019; CNEI, 2019) that are from two days to six weeks long. There is limited research, however, to inform specific clinical instructor competencies to guide this education (Glynn et al., 2014). Core competencies for the academic nurse educator were developed in the United States by the National League for Nursing (NLN) in 2005. In 2016, the WHO established its Nurse Educator Core Competencies (NECC) to guide the development of a "competence-based curriculum encompassing the cognitive, affective and psychomotor skills and behaviours expected of nurse teachers" (p. 7). The WHO emphasized that these are "the minimum competencies that a qualified nurse educator should possess" (p. 11). The competencies were chosen based on an extensive literature review, a global Delphi survey, validation guided by international experts, and integration of competency domains and core competencies within the domains of learning to help facilitate the development of comprehensive educational programs and assessment methods (pp. 8-10). Although both frameworks focus on the broader nurse educator role, they offer guidance for the design of CI-specific competencies. Mapping of the eight competency domains of the NLN and WHO revealed that they were similar. The WHO NECC framework was chosen to guide this study because it was developed more recently, was created

for an international audience, and offered a more explicit description of the sub-competencies. The NECC are organized in eight domains with 37 specific competencies (see Table 1). 


\section{Table 1}

\section{Domains of Nurse Educator Core Competencies}

\begin{tabular}{|c|c|}
\hline Domain and Core Competency & Competencies \\
\hline $\begin{array}{l}\text { 1: Theories and principles of adult } \\
\text { learning. } \\
\text { Core Competency: Nurse educators } \\
\text { possess a sound understanding of } \\
\text { contemporary educational theories, } \\
\text { principles and models underlying the } \\
\text { design of curricula and the value of } \\
\text { adult learning. }\end{array}$ & $\begin{array}{l}\text { 1.1: Exhibit an understanding of conceptual and theoretical foundations } \\
\text { and principles related to health profession education and adult learning. } \\
\text { 1.2: Analyse domains of learning (cognitive, affective and psychomotor) } \\
\text { and their application in different academic contexts. } \\
\text { 1.3: Demonstrate knowledge of curriculum development, which } \\
\text { incorporates educational theories, principles and models. }\end{array}$ \\
\hline $\begin{array}{l}\text { 2: Curriculum and implementation. } \\
\text { Core Competency: Nurse educators } \\
\text { demonstrate the skills and abilities to } \\
\text { design, implement, monitor and } \\
\text { manage curricula based on sound, } \\
\text { contemporary educational models, } \\
\text { principles, and best evidence. }\end{array}$ & $\begin{array}{l}\text { 2.1: Design curricula, which support context-based nursing practice } \\
\text { needs and reflect current trends in the healthcare environment. } \\
\text { 2.2: Develop and implement a relevant course based on innovative } \\
\text { teaching and learning strategies that facilitate active learning and } \\
\text { achievement of learning outcomes. } \\
\text { 2.3: Facilitate theoretical and clinical reasoning among diverse learners } \\
\text { with different learning styles and unique learning needs. } \\
\text { 2.4: Integrate evidence-based teaching and learning processes, and help } \\
\text { learners interpret and apply evidence in their clinical learning } \\
\text { experiences. } \\
\text { 2.5: Create and maintain a safe environment that is conducive to learning } \\
\text { in theoretical, clinical simulation and practice settings. } \\
\text { 2.6: Use transformational and experiential strategies that develop } \\
\text { context-based nursing knowledge, skills and professional behaviours. } \\
\text { 2.7: Incorporate and engage learners with the use of appropriate } \\
\text { information technologies (including eLearning, eHealth) in teaching and } \\
\text { learning processes. } \\
\text { 2.8: Formulate evaluation tools for teaching and learning experiences } \\
\text { and use results to monitor learners' performance and desired outcomes of } \\
\text { courses. }\end{array}$ \\
\hline $\begin{array}{l}\text { 3: Nursing practice. } \\
\text { Core Competency: Nurse educators } \\
\text { maintain current knowledge and } \\
\text { skills in theory and practice, based on } \\
\text { the best available evidence. }\end{array}$ & $\begin{array}{l}\text { 3.1: Maintain competence in nursing practice. } \\
\text { 3.2: Practice nursing in ways that reflect evidence-based, up-to-date } \\
\text { knowledge. } \\
\text { 3.3: Plan a variety of teaching and learning activities that foster creativity } \\
\text { and innovation of nursing practice and the health-care environment. }\end{array}$ \\
\hline $\begin{array}{l}\text { 4: Research and evidence } \\
\text { Core Competency: Nurse educators } \\
\text { develop their critical inquiry and the } \\
\text { ability to conduct research and utilize } \\
\text { findings to identify and solve } \\
\text { educational and practice-based } \\
\text { problems. }\end{array}$ & $\begin{array}{l}\text { 4.1: Synthesize, use and generate knowledge pertinent to nursing } \\
\text { education and practice. } \\
\text { 4.2: Engage in debate and reflection with peers to generate and apply } \\
\text { new ideas that contribute to the improvement of nursing education and } \\
\text { practice. } \\
\text { 4.3: Develop future nurse scholars by nurturing a spirit of sharing, } \\
\text { inquiry and self-reflection. } \\
\text { 4.4: Engage in scholarly writing and publication. }\end{array}$ \\
\hline $\begin{array}{l}\text { 5: Communication, collaboration and } \\
\text { partnership. } \\
\text { Core Competency: Nurse educators } \\
\text { demonstrate effective communication } \\
\text { skills that promote collaborative } \\
\text { teamwork and enhance partnership } \\
\text { among health profession educational } \\
\text { and clinical practice. }\end{array}$ & $\begin{array}{l}\text { 5.1: Demonstrate intercultural and interdisciplinary competence in the } \\
\text { teaching and nursing practice. } \\
\text { 5.2: Communicate best practice in nursing education with peers, students } \\
\text { and other stakeholders. } \\
\text { 5.3: Facilitate and foster teamwork and collaboration at educational and } \\
\text { clinical institutions both locally and with the wider regional and } \\
\text { international community. }\end{array}$ \\
\hline $\begin{array}{l}\text { 6: Ethical/Legal principles and } \\
\text { professionalism. }\end{array}$ & $\begin{array}{l}\text { 6.1: Promote social justice and the protection of human rights in teaching } \\
\text { and learning processes and in the health care environment. }\end{array}$ \\
\hline
\end{tabular}




\begin{tabular}{|c|c|}
\hline Domain and Core Competency & Competencies \\
\hline $\begin{array}{l}\text { Core Competency: Nurse educators } \\
\text { demonstrate professionalism } \\
\text { including legal, ethical and } \\
\text { professional values as a basis for } \\
\text { developing nursing education } \\
\text { policies, procedures and decision- } \\
\text { making. }\end{array}$ & $\begin{array}{l}\text { 6.2: Promote ethical and legal principles of integrity, academic honesty, } \\
\text { flexibility and respect through role modelling. } \\
\text { 6.3: Participate in ongoing professional self-development and support the } \\
\text { professional learning of colleagues. } \\
\text { 6.4: Facilitate professionalization for learners by creating learners' self- } \\
\text { reflection, personal goal setting and socialization within the role of the } \\
\text { nurse. } \\
\text { 6.5: Maintain a professional record (curriculum vitae and/or portfolio) } \\
\text { that demonstrates current nursing and teaching competence. }\end{array}$ \\
\hline $\begin{array}{l}\text { 7: Monitoring and evaluation } \\
\text { Core Competency: Nurse educators } \\
\text { utilize a variety of strategies to } \\
\text { monitor and evaluate nursing } \\
\text { programmes, the curricula and } \\
\text { mastery of student learning. }\end{array}$ & $\begin{array}{l}\text { 7.1: Monitor, assess and evaluate teaching and learning methods and } \\
\text { experiences in relation to nursing outcomes and learner needs. } \\
\text { 7.2: Evaluate own teaching competencies by seeking input from peers } \\
\text { and students. Use feedback to improve role effectiveness. } \\
\text { 7.3: Develop a variety of assessment tools and methods to ascertain } \\
\text { student competence in cognitive, affective and psychomotor domains. } \\
\text { Provide timely constructive verbal and written feedback to learners. } \\
\text { 7.4: Foster learners' self- assessment skills and reflection on teaching } \\
\text { and learning activities. } \\
\text { 7.5: Collaborate with colleagues to develop, manage and evaluate } \\
\text { curriculum, programmes, courses, and clinical teaching and learning } \\
\text { experiences. }\end{array}$ \\
\hline $\begin{array}{l}\text { 8: Management, leadership and } \\
\text { advocacy. } \\
\text { Core Competency: Nurse educators } \\
\text { demonstrate the skills of system } \\
\text { management and leadership to create } \\
\text { maintain and develop desired nursing } \\
\text { programmes and shape the future of } \\
\text { education institutions. }\end{array}$ & $\begin{array}{l}\text { 8.1: Incorporate the mission and strategic plan of the parent institution } \\
\text { with the goals of the nursing programme when proposing and managing } \\
\text { change. } \\
\text { 8.2: Assume leadership roles at various levels for institutional } \\
\text { governance, education development and enhancing nursing practice. } \\
\text { 8.3: Demonstrate effective and efficient human and financial resource } \\
\text { management. } \\
\text { 8.4: Engage in quality reviews to assess strengths and weaknesses of the } \\
\text { programme based on set criteria and use the results for benchmarking } \\
\text { and ongoing progress. } \\
\text { 8.5: Use a variety of advocacy strategies to promote nursing education } \\
\text { and practice. } \\
\text { 8.6: Identify opportunities for positive change and effectively manage } \\
\text { the change process both at individual and organizational levels }\end{array}$ \\
\hline
\end{tabular}

Source: WHO (2016, pp. 11-16)

The purpose of this study was to address the gap in the literature regarding CI-specific competencies by conducting an exploratory study to identify the CIs perceptions of the importance of the NECC and whether they practised them in their current clinical teaching role in a baccalaureate nursing program in an Ontario university.

Donabedian's (1988) structure-process-outcome conceptual framework guided this study (see Figure 1). The framework hypothesizes a sequential relationship between three dimensions that influence quality: structure, process, and outcome. Structure represents the characteristics of the setting or people who are being studied, the tools and resources they have at their disposal, and the physical and organizational settings in which they work (Donabedian, 1988). The structure refers to the structures in the nursing school (e.g., policies, procedures, and resources) that support the CIs to meet their role responsibilities; in this study it is defined as the NECC. Process refers to the steps to achieve the outcomes. The process would be an education curriculum guided by the CI-specific competencies (that could be offered by nursing schools or professional organizations). Outcome is the future state as a result of the structure and process and reflects their effectiveness 
(Donabedian, 1988). These are hypothesized to include achievement of the CI-specific competencies, CI role satisfaction, and student satisfaction with the CI role. The structure component (NECC) is the focus of this study.

\section{Figure 1}

Donabedian (1988): Structure, Process, and Outcome

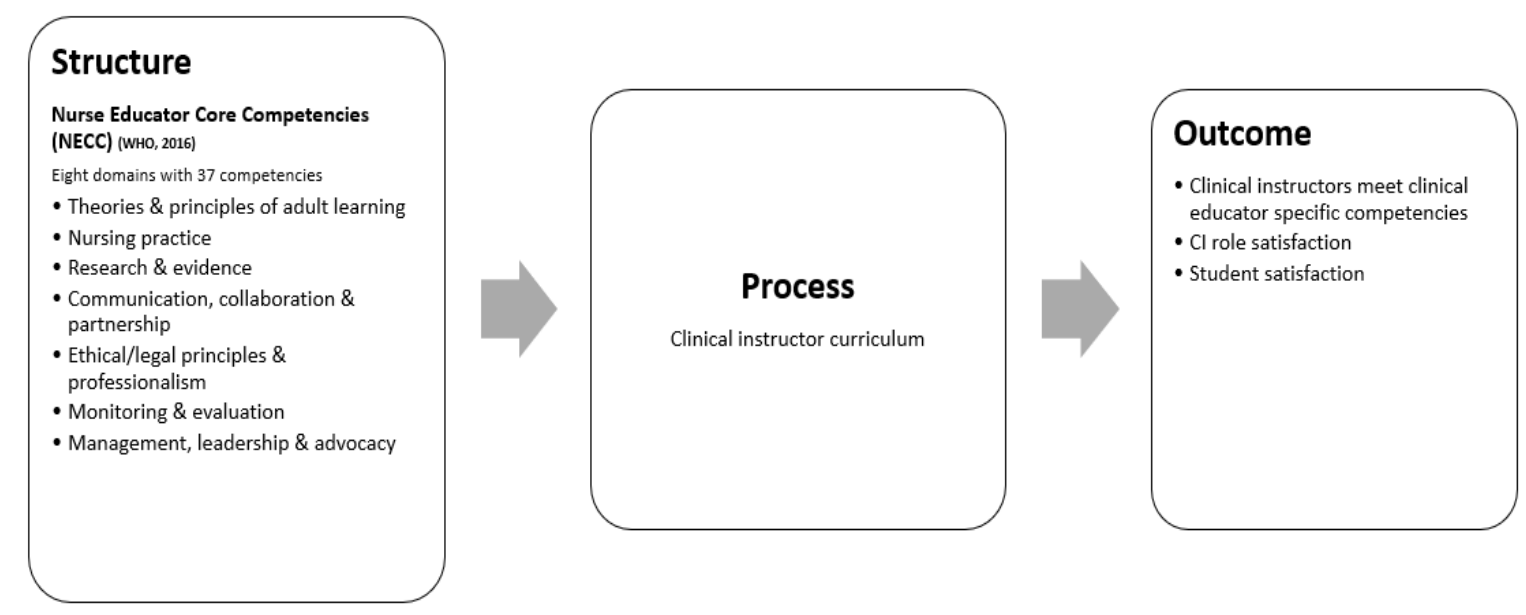

\section{Methodology}

This study used an exploratory quantitative design. It was conducted in a baccalaureate of nursing program in an Ontario university. Convenience sampling was used to survey participants who were employed contractually to teach. CIs who also taught theory courses were excluded. There were 113 CIs available to participate; 27 CIs (23.9\%) completed the survey.

A self-report survey guided by the WHO's NECC was developed. The survey comprised three sections. Section one asked the respondent their level of agreement with the importance of the 37 competencies that a CI should know to assume the role; section two asked respondents to consider their own role as a CI and rate their personal implementation of each of the 37 competencies in their current practice. A 5-point Likert scale ranging from 1 (strongly disagree) to 5 (strongly agree) was used. Section three collected demographic data.

Following ethical review and subsequent approval, a Qualtrics survey was distributed electronically using a three-contact email strategy at weekly intervals (Dillman et al., 2009). Respondents were invited to participate in a voluntary draw to win one of two gift cards. Draw information was collected separately from the completed surveys. The data collection occurred from March 26 to April 30, 2018. Data analysis procedures were performed with the IBM SPSS Statistics (version 25). Dependent data collected on the perceptions of the importance of the competencies and the practice of these competencies in their current roles as clinical instructors were compared using Wilcoxon signed ranks, which is most appropriate for analysis of small samples and ordinal data with no assumption about normal distribution (Imam et al., 2014).

\section{Results}

Descriptive statistics were used to describe the sample characteristics (see Table 2). There were 27 respondents: 19 (70.4\%) were master's-prepared nurses and $8 \mathrm{had}$ a BScN as their terminal 
degree. Over half of the participants (51.9\%) had 21 years or more of experience as RNs; $40 \%$ ( $n$ $=11$ ) were employed solely by the university. The respondents were an experienced group; only $4(14.8 \%)$ had taught 1 to 10 clinical groups; the remainder had taught from 11 to over 50. Six (22.2\%) had taken a clinical teaching course.

\section{Table 2}

Sample Characteristics

\begin{tabular}{lr}
\hline \multicolumn{1}{c}{ Variable } & $N=27(\%)$ \\
\hline Education & \\
\hline \multicolumn{1}{l}{ BScN } & $8(29.6 \%)$ \\
\hline \multicolumn{1}{l}{ Master's prepared } & $8(29.6 \%)$ \\
\hline Years as RN & $1(3.7 \%)$ \\
\hline 4-6 years & $2(7.4 \%)$ \\
\hline $7-10$ years & $8(29.6 \%)$ \\
\hline $11-15$ years & $2(7.4 \%)$ \\
\hline $16-20$ years & $14(51.9 \%)$ \\
\hline 21 years and over & $11(40.7 \%)$ \\
\hline Employment in addition to CI role & $2(7.4 \%)$ \\
\hline Not employed & $9(33.3 \%)$ \\
\hline Casual & $5(18.5 \%)$ \\
\hline Part-time & \\
\hline Full-time & $4(14.8 \%)$ \\
\hline Total number of clinical groups taught & $7(25.9 \%)$ \\
\hline $1-10$ & $4(14.8 \%)$ \\
\hline $11-20$ & $4(14.8 \%)$ \\
\hline $21-30$ & $5(18.5 \%)$ \\
\hline $31-40$ & $3(11.1 \%)$ \\
\hline $41-50$ & $6(22.2 \%)$ \\
\hline 51 or more & $21(77.8 \%)$ \\
\hline Clinical teaching course & \\
\hline Yes & \\
\hline No &
\end{tabular}

Participants' responses to the importance of the CI competencies and their implementation of them in their CI role are displayed in Table 3. Overall, respondents indicated that most of the competencies were important (and therefore applicable) to their role. For domain 1, theories and principles of adult learning, respondents agreed that all the competencies were important, and they implemented them in their $\mathrm{CI}$ role. For domain 2, curriculum and implementation competencies, respondents identified that seven of eight were important although they were not able to implement four of them: designing curricula, developing and implementing a relevant course, engaging learners with use of appropriate IT, and formulating evaluation tools for teaching and learning experiences. They strongly disagreed (median $=1$ ) that creating and maintaining a safe environment conducive to learning was an important competency but strongly agreed that they executed this in their role (median $=5 ; p<.001$ ). For domain 3 , nursing practice, respondents 
indicated that these competencies were important. However, the competency focused on evidencebased practice, although important, was not practiced in their current role. For domain 4, research and evidence, three of the four were deemed very important. Engaging in debate and reflection with peers to generate new ideas, however, was not practised. Engaging in scholarly writing and publication was perceived as only moderately important (median $=3$ ) and not consistently practiced (median $=2$ ). For domain 5, communication, collaboration, and partnership, the three competencies were important, but two that focused on communicating best practices in nursing education and facilitating and fostering teamwork and collaboration at educational and clinical institutions locally, regionally. and internationally were not practiced. For domain 6, ethical/legal principles and professionalism, respondents agreed that the competencies were important and that they were implemented in their role. In domain 7, monitoring and evaluation, all five competencies were deemed important; only one focused on collaborating with colleagues to develop, manage, and evaluate curriculum was not practised. The six competencies in domain 8, management, leadership, and advocacy, were all identified as important. Four, however, were not consistently practised by all participants: assuming leadership roles at various levels, engaging in quality reviews to assess strengths and weaknesses of the program, using a variety of advocacy strategies to promote nursing education and practice, and identifying opportunities for positive change and effectively managing the change process.

\section{Table 3}

Competencies by Domain: Importance and Implementation

\begin{tabular}{|c|c|c|c|c|c|c|c|}
\hline \multirow[t]{2}{*}{ \# } & \multirow[t]{2}{*}{ Domains and Competencies } & \multicolumn{2}{|c|}{ Importance for CI Role } & \multicolumn{2}{|c|}{$\begin{array}{l}\text { Implementation in CI } \\
\text { Role }\end{array}$} & \multirow[b]{2}{*}{$\mathrm{Z}$} & \multirow[b]{2}{*}{$p$} \\
\hline & & $\mathrm{M} \pm \mathrm{SD}$ & Median & $\mathrm{M} \pm \mathrm{SD}$ & Median & & \\
\hline \multicolumn{8}{|c|}{ 1. Theories and principles of adult learning } \\
\hline 1.1 & $\begin{array}{l}\text { Understand foundations of } \\
\text { learning }\end{array}$ & $4.44 \pm .80$ & 5.00 & $4.19 \pm .79$ & 4.00 & -1.507 & .132 \\
\hline 1.2 & Analyse domains of learning & $4.26 \pm .94$ & 4.00 & $4.04 \pm .71$ & 4.00 & -1.604 & .109 \\
\hline 1.3 & $\begin{array}{l}\text { Knowledge of curriculum } \\
\text { development }\end{array}$ & $3.89 \pm .85$ & 4.00 & $3.59 \pm .97$ & 4.00 & -1.537 & .124 \\
\hline \multicolumn{8}{|c|}{ 2. Curriculum and implementation } \\
\hline 2.1 & Design curricula & $4.19 \pm .83$ & 4.00 & $2.78 \pm 1.16$ & 2.00 & -1.951 & $.051 *$ \\
\hline 2.2 & Develop/implement course & $4.26 \pm .76$ & 4.00 & $3.74 \pm .94$ & 4.00 & -2.828 & $.005 *$ \\
\hline 2.3 & $\begin{array}{l}\text { Facilitate theoretical and clinical } \\
\text { reasoning }\end{array}$ & $4.37 \pm .57$ & 4.00 & $4.26 \pm .71$ & 4.00 & -.832 & .405 \\
\hline 2.4 & $\begin{array}{l}\text { Integrate evidence-based } \\
\text { teaching and learning processes }\end{array}$ & $4.59 \pm .57$ & 5.00 & $4.41 \pm .50$ & 4.00 & -1.667 & .096 \\
\hline 2.5 & $\begin{array}{l}\text { Create safe learning } \\
\text { environment }\end{array}$ & $2.15 \pm 1.75$ & 1.00 & $4.63 \pm .57$ & 5.00 & -4.129 & $<.001^{*}$ \\
\hline 2.6 & $\begin{array}{l}\text { Use transformational and } \\
\text { experiential strategies }\end{array}$ & $4.15 \pm .82$ & 4.00 & $3.93 \pm .68$ & 4.00 & -1.897 & .058 \\
\hline 2.7 & Incorporate use of IT & $4.19 \pm .68$ & 4.00 & $3.63 \pm .93$ & 4.00 & -2.862 & $.004 *$ \\
\hline 2.8 & Formulate evaluation tools & $4.19 \pm .68$ & 4.00 & $3.52 \pm 1.16$ & 4.00 & -2.753 & $.006 *$ \\
\hline \multicolumn{8}{|c|}{ 3. Nursing practice } \\
\hline 3.1 & $\begin{array}{l}\text { Maintain competence in nursing } \\
\text { practice }\end{array}$ & $4.81 \pm .40$ & 5.00 & $4.63 \pm .49$ & 5.00 & -1.667 & .096 \\
\hline 3.2 & $\begin{array}{l}\text { Practice reflects evidence-based } \\
\text { up to date knowledge }\end{array}$ & $4.74 \pm .45$ & 5.00 & $4.52 \pm .58$ & 5.00 & -2.121 & $.034 *$ \\
\hline 3.3 & $\begin{array}{l}\text { Plan teaching/ learning activities } \\
\text { that foster creativity/ innovation }\end{array}$ & $4.22 \pm .64$ & 4.00 & $4.19 \pm .96$ & 4.00 & -.131 & .896 \\
\hline
\end{tabular}




\begin{tabular}{|c|c|c|c|c|c|c|c|}
\hline \multicolumn{8}{|c|}{ 4. Research and evidence } \\
\hline 4.1 & $\begin{array}{l}\text { Synthesize, use and generate } \\
\text { knowledge }\end{array}$ & $4.19 \pm .83$ & 4.00 & $4.33 \pm .68$ & 4.00 & -.504 & .614 \\
\hline 4.2 & $\begin{array}{l}\text { Engage in debate and reflection } \\
\text { with peers to generate new ideas }\end{array}$ & $4.44 \pm .58$ & 4.00 & $4.11 \pm .85$ & 4.00 & -2.124 & $.034^{*}$ \\
\hline 4.3 & Develop future nurse scholars & $4.63 \pm .57$ & 5.00 & $4.44 \pm .64$ & 5.00 & -1.508 & .132 \\
\hline 4.4 & $\begin{array}{l}\text { Engage in scholarly writing and } \\
\text { publication }\end{array}$ & $2.96 \pm .71$ & 3.00 & $2.63 \pm 1.15$ & 2.00 & -1.265 & .206 \\
\hline \multicolumn{8}{|c|}{ 5. Communication, collaboration and partnership } \\
\hline 5.1 & $\begin{array}{l}\text { Demonstrate intercultural and } \\
\text { interdisciplinary competence }\end{array}$ & $4.22 \pm .64$ & 4.00 & $4.11 \pm .64$ & 4.00 & -1.342 & .180 \\
\hline 5.2 & $\begin{array}{l}\text { Communicate best practice in } \\
\text { nursing education }\end{array}$ & $4.48 \pm .58$ & 5.00 & $4.19 \pm .92$ & 4.00 & -1.999 & $.046^{*}$ \\
\hline 5.3 & $\begin{array}{l}\text { Facilitate and foster teamwork } \\
\text { and collaboration }\end{array}$ & $4.30 \pm .78$ & 4.00 & $3.93 \pm 1.00$ & 4.00 & -2.352 & $.019^{*}$ \\
\hline \multicolumn{8}{|c|}{ 6. Ethical/Legal principles and professionalism } \\
\hline 6.1 & $\begin{array}{l}\text { Promote social justice and } \\
\text { protection of human rights }\end{array}$ & $4.48 \pm .64$ & 5.00 & $4.26 \pm .71$ & 4.00 & -1.732 & .083 \\
\hline 6.2 & $\begin{array}{l}\text { Promote ethical and legal } \\
\text { principles }\end{array}$ & $4.78 \pm .42$ & 5.00 & $4.67 \pm .560$ & 5.00 & -1.134 & .257 \\
\hline 6.3 & $\begin{array}{l}\text { Participate in ongoing } \\
\text { professional self-development }\end{array}$ & $4.56 \pm .58$ & 5.00 & $4.26 \pm .90$ & 4.00 & -1.642 & .101 \\
\hline 6.4 & $\begin{array}{l}\text { Facilitate professionalization for } \\
\text { learners }\end{array}$ & $4.33 \pm .73$ & 4.00 & $4.22 \pm .80$ & 4.00 & -1.342 & .180 \\
\hline 6.5 & Maintain professional record & $4.15 \pm .77$ & 4.00 & $3.85 \pm 1.10$ & 4.00 & -1.662 & .096 \\
\hline \multicolumn{8}{|c|}{ 7. Monitoring and evaluation } \\
\hline 7.1 & $\begin{array}{l}\text { Monitor, assess and evaluate } \\
\text { teaching and learning methods }\end{array}$ & $4.33 \pm .62$ & 4.00 & $4.33 \pm .56$ & 4.00 & .000 & 1.00 \\
\hline 7.2 & $\begin{array}{l}\text { Evaluate own teaching } \\
\text { competencies }\end{array}$ & $4.56 \pm .58$ & 5.00 & $4.30 \pm .87$ & 4.00 & -1.387 & .166 \\
\hline 7.3 & $\begin{array}{l}\text { Develop assessment tools/ } \\
\text { methods to ascertain student } \\
\text { competence }\end{array}$ & $4.41 \pm .64$ & 4.00 & $4.19 \pm .74$ & 4.00 & -1.428 & .153 \\
\hline 7.4 & $\begin{array}{l}\text { Foster learners' self-assessment } \\
\text { skills and reflection }\end{array}$ & $4.41 \pm .69$ & 5.00 & $4.30 \pm .72$ & 4.00 & -.832 & .405 \\
\hline 7.5 & $\begin{array}{l}\text { Collaborate with colleagues to } \\
\text { on curriculum }\end{array}$ & $4.11 \pm .75$ & 4.00 & $3.15 \pm 1.20$ & 3.00 & -3.579 & $<.001 *$ \\
\hline \multicolumn{8}{|c|}{ 8. Management, leadership and advocacy } \\
\hline 8.1 & $\begin{array}{l}\text { Incorporate mission and } \\
\text { strategic plan }\end{array}$ & $3.78 \pm .93$ & 4.00 & $3.41 \pm 1.05$ & 3.00 & -1.781 & .075 \\
\hline 8.2 & Assume leadership roles & $3.85 \pm .66$ & 4.00 & $3.07 \pm 1.07$ & 3.00 & -3.087 & $.002 *$ \\
\hline 8.3 & $\begin{array}{l}\text { Demonstrate human and } \\
\text { financial resource management }\end{array}$ & $3.67 \pm .78$ & 4.00 & $3.59 \pm 1.12$ & 4.00 & -.504 & .614 \\
\hline 8.4 & Engage in quality reviews & $4.15 \pm .66$ & 4.00 & $3.07 \pm 1.17$ & 3.00 & -3.484 & $<.001 *$ \\
\hline 8.5 & Use advocacy strategies & $4.37 \pm .57$ & 4.00 & $3.85 \pm .91$ & 4.00 & -2.725 & $.006^{*}$ \\
\hline 8.6 & $\begin{array}{l}\text { Identify opportunities for } \\
\text { change }\end{array}$ & $4.26 \pm .81$ & 4.00 & $3.70 \pm .87$ & 4.00 & -3.260 & $.001^{*}$ \\
\hline
\end{tabular}

Note: Complete wording of competency is found in Table 1.

* Statistically significant results at $\alpha$ of $\leq 0.05$.

\section{Discussion}

CIs assume an essential role in nursing schools. There are currently no standardized competencies to guide the educational preparation for this role in Canada. This study explored 
whether WHO (2016) NECC, developed for the broad role of nurse educator, were relevant to the clinically focused nurse educator role. A group of current clinical instructors were surveyed to determine the importance of the 37 competencies in their CI role and whether they practised them. Although the sample size was small, most of the participants in this study were experienced RNs with significant CI experience. Their responses provide valuable insights and a first step into developing CI-specific competencies.

The NECC were designed to guide the development of competence-based curriculum for nurse educators (WHO, 2016, p. 6). Respondents agreed with the importance of and practised most of them. This finding supports that the NECC have merit in guiding CI-specific competencies.

There were, however, competencies deemed important but not practised; these included using information technology, facilitating and fostering teamwork, and maintaining a professional record, and competencies relating to program and change management. These findings may indicate a problem with how the competency was worded (e.g., too broad for the CI role), lack of clarity on CI role expectations by the institution, and/or an indication that the CIs lacked the knowledge to meet the competency. For example, although information technology is an entry to practice competency, nurse educators have been found to have gaps in knowledge (Pilarski, 2011); therefore, it is not surprising that it might be less frequently practised. As well, practice gaps in two specific items focused on communication, collaboration, and partnership (domain 5) were noteworthy: (1) communicating best practices, and (2) facilitating and fostering teamwork and collaboration at educational and clinical institutions. These are valuable competencies for CIs. Since the survey did not request rationale for these gaps, it is unclear why CIs were not engaged in these practices.

Some competencies (e.g., curriculum development, scholarly writing and publication, creation of a safe environment, change management, institutional governance, and human and financial resource management) were deemed less important. There are several reasons for these findings. First, some competencies (e.g., curriculum development, publishing) were not expected in the CI role where the study was conducted. Second, the NECC reflect the broader nurse educator role and require revision to reflect $\mathrm{CI}$-specific role expectations. For example, one competency included engagement in both scholarly writing and publishing. Scholarly writing is an expectation of CIs who provide guidance and evaluate students' clinical assignments (Oermann, 2015); publishing, however, is not generally a requirement in the CI role. Third, a lack of consensus and clarity on CI-specific competencies may have resulted in them not being prepared to carry out some of the expected education.

CI responses to the creation and maintenance of a safe environment were interesting but not unexpected based on the literature. Respondents did not perceive that creating and maintaining the safety of the environment was an important competency, but they identified that they implemented it in practice. As "visitors" in clinical placement sites, CIs perceive that they are not in control of the safety of the environment (Luhanga, 2018). Nursing schools, however, would expect that CIs possess competencies in this regard. This finding lends support to the need for more education in this specialty for both faculty and CIs.

Since the completion of this study, further research has been completed by the NLN in the United States. They have worked to further develop their core competencies and framework to support the specialized needs of CIs (Christensen \& Simmons, 2020; Schellenbarger, 2019). 


\section{Implications for Research and Education}

There are several implications of these findings for future research and education. First, the NECCs need to be revised to ensure clarity of language and accuracy that reflect the CI role. Face and content validity of these revised competencies would need to be established through testing with faculty and CIs (El-Masri, 2016). The Delphi method could be employed to obtain consensus from a group of experts (Powell, 2003). Finally, the CI-specific competencies could be used in the design of future CI education programs and to evaluate current programs. This would allow for the standardization of CI education across Canada, lay the groundwork for the development of a $\mathrm{CI}$ certification program through CNA or CNEI, and formally acknowledge the CI role as a nursing specialty.

The WHO (2016) recommends that competencies be assessed at three levels. These recommendations offer guidance to nursing schools and their accrediting bodies. These include assessments (1) by the CI for self-evaluation, (2) by the educational institution to assess educational and professional development needs of the CI, and (3) at the national level to evaluate whether program standards are being met and to inform planning for appropriate interventions.

\section{Limitations}

Limitations for this study included a small sample size. As well, all research participants were drawn from one school of nursing; therefore, the findings may not be generalizable to other populations. Future research should include larger samples from different locations.

The survey was a structured questionnaire with Likert responses and respondents were unable to provide comments on their interpretation of specific competencies.

\section{Conclusion}

The literature confirms that nursing education has changed over the past decades, and the reliance on part-time educators to assume the role of CIs has increased. Currently, there is a lack of consensus on the competencies they require to carry out the clinical role. This small study has highlighted the need to clarify and standardize CI-specific competencies. Nurse educator competencies (WHO, 2016) were developed to "enable educators to effectively contribute to the attainment of high-quality education and the production of effective, efficient and skilled nurses"

(p. 5). CIs will be able to contribute more effectively to these outcomes with CI-specific competencies to guide their preparation and practice. National competencies will serve as a foundation for CI preparation in Canada that has the promise of increasing both student satisfaction and CI job satisfaction, improving the quality and safety of clinical education, decreasing the theory to practice gap in undergraduate curricula, and ultimately impacting all recipients of care in the health care system. 


\section{References}

Andrew, S., Halcomb, E. J., Jackson, D., Peters, K., \& Salamonson, Y. (2010). Sessional teachers in a BN program: Bridging the divide or widening the gap? Nurse Education Today, 30(5), 453-457.

Arnold, E., \& Boggs, K. U. (2016). Interpersonal relationships: Professional communication skills for nurses (7th ed.). Elsevier Saunders.

Blauvelt, M. J., \& Spath, M. L. (2008). Passing the torch: A faculty mentoring program at one school of nursing. Nursing Education Perspectives, 29(1), 29-33.

Bloomberg Faculty of Nursing. (2019). The foundations and scholarship of clinical teaching. University of Toronto.

Canadian Association of Schools of Nursing. (2012). Ties that bind: The evolution of education for professional nursing in Canada from the 17th to the 21 st century.

Canadian Association of Schools of Nursing. (2013). Nursing informatics teaching toolkit: Supporting the integration of the CASN nursing informatics competencies into nursing curricula. http://digitalhealth.casn.ca/content/user_files/2017/12/FINAL-EN_NursingInformatics-Teaching-Toolkit.pdf

Canadian Association of Schools of Nursing. (2015). National nursing education framework: Final report. http://www.casn.ca/wp-content/uploads/2014/12/Framwork-FINAL-SBNov-30-20151.pdf

Canadian Institute for Health Information. (2017). Regulated nurses, 2017-Canada and jurisdictional highlights. https://secure.cihi.ca/free_products/regulated-nurses-2017-PThighlights-en-web.pdf

Canadian Nurse Educator Institute. (2019). Certification programs. http://cnei-icie.casn.ca/ourprograms/

Canadian Nurses Association. (2019). Certification nursing practice specialties. https://www.cna-aiic.ca/en/certification/get-certified/certification-nursing-practicespecialties

Carlson, J. S. (2015). Orientation, evaluation, and integration of part-time nursing faculty. International Journal of Nursing Education Scholarship, 12(1), 1-8. https://doi.org/http://dx.doi.org/10.1515/ijnes-2015-0036

Christensen, L. S., \& Simmons, L. E. (2020). The scope of practice for academic nurse educators and academic clinical nurse educators (3rd ed.). National League for Nursing.

Dahlke, S., Baumbusch, J., Affleck, F., \& Kwon, J. (2012). The clinical instructor role in nursing education: A structured literature review. Journal of Nursing Education, 51(12), 692696. https://doi.org/10.3928/01484834-20121022-01

Dillman, D., Smyth, J., \& Christian, L. (2009). Internet, mail and mixed mode surveys: The tailored design method. John Wiley \& Sons.

Donabedian, A. (1988). The quality of care: How can it be assessed? JAMA, 260(12), 17431748. https://doi.org/10.1001/jama.1988.03410120089033

El-Masri, M. M. (2016). Reliability of psychometric instruments. Canadian Nurse, 112(5), 16. 
Gazza, E. A., \& Shellenbarger, T. (2005). Successful enculturation: Strategies for retaining newly hired nursing faculty. Nurse Educator, 30(6), 251-254.

Glynn, D. M., Kelsey, W., Taylor, M., Lynch, A., \& DeLibertis, J. (2014). Nursing clinical instructor needs assessment. Journal of Nursing and Care, 3(3), 1-3.

Hewitt, P., \& Lewallen, L. (2010). Ready, set, teach! How to transform the clinical nurse expert into the part-time clinical nurse instructor. The Journal of Continuing Education in Nursing, 41(9), 403-407. https://doi.org/http://dx.doi.org/10.3928/00220124-2010050310

Imam, A., Usman, M., \& Chiawa, M. A. (2014). On consistency and limitation of paired t-test, sign and Wilcoxan sign rank test. IOSR Journal of Mathematics, 10(1), 01-06.

Jennings, A., \& Brett, C. (2018). The pedagogical practices of clinical nurse educators. Quality Advancement in Nursing Education, 4(2), Article 7. https://doi.org/10.17483/23686669.1142

Knox, J. E., \& Mogan, J. (1987). Characteristics of "best" and "worst" clinical teachers as perceived by university nursing faculty and students. Journal of Advanced Nursing 12(3), 331-337.

Luhanga, F. L. (2018). The traditional-faculty supervised teaching model: Nursing faculty and clinical instructors' perspectives. Journal of Nursing Education and Practice, 8(6), 124137. https://doi.org/10.5430/jnep.v8n6p124

National League for Nursing. (2005). Core competencies of nurse educators with task statements. http://www.wgec.org/resources/art/nursing-core-competencies.pdf

National League for Nursing. (2019). Nurse educator core competency: Competencies for the academic nurse educator. http://www.nln.org/professional-developmentprograms/competencies-for-nursing-education/nurse-educator-core-competency

Nehring, V. (1990). Nursing clinical teacher effectiveness inventory: A replication study of the characteristics of "best" and "worst" clinical teachers as perceived by nursing faculty and students. Journal of Advanced Nursing 15, 934-940.

O’Rae, A., Langille, J., Li, A., Sealock, K., \& Rutherford, G. (2017). The evolving role of a clinical instructor in an integrated undergraduate nursing curriculum. Journal of Nursing Education and Practice, 7(4), 87-95. https://doi.org/10.5430/jnep.v7n4p87

Oermann, M. (2015). Teaching in nursing and role of the educator: The complete guide to best practice in teaching, evaluation and curriculum development. Springer Publishing Company.

Penn, B. K., Dodge Wilson, L., \& Rosseter, R. (2008). Transitioning from nursing practice to a teaching role. The Online Journal of Issues in Nursing, 13(3). http://ojin.nursingworld.org/MainMenuCategories/ANAMarketplace/ANAPeriodicals/OJ IN/TableofContents/vol132008/No3Sept08/NursingPracticetoNursingEducation.aspx

Pilarski, T. (2011). Where is nursing informatics in undergraduate nursing education? Canadian Journal of Nursing Informatics, 5(4), Article Two. http://cjni.net/journal/?p=1041 
Powell, C. (2003). The Delphi technique: Myths and realities. Journal of Advanced Nursing, 41(4), 376-382. https://doi.org/10.1046/j.1365-2648.2003.02537.x

Registered Nurses' Association of Ontario. (2016). Practice education in nursing.

Reid, T. P., Hinderer, K. A., Jarosinski, J. M., Mister, B. J., \& Seldomridge, L. A. (2013). Expert clinician to clinical teacher: Developing a faculty academy and mentoring initiative. Nurse Education in Practice, 13(4), 288-293. http://dx.doi.org/10.1016/j.nepr.2013.03.022

Schellenbarger, T. (2019). Clinical nurse educator competencies: Creating an evidence-based practice for academic clinical nurse educators. National League for Nursing.

Wong, J., \& Wong, S. (1987). Towards effective clinical teaching in nursing. Journal of Advanced Nursing, 12(4), 505-513. https://doi.org/10.1111/1365-2648.ep13107622

World Health Organization. (2016). Nurse educator core competencies. http://who.int/hrh/nursing_midwifery/nurse_educator050416.pdf

Zabat Kan, E., \& Stabler-Haas, S. (2014). Fast facts for the clinical nursing instructor: Clinical teaching in a nutshell (2nd ed.). Springer Publishing Company. 